\title{
Knowledge Sharing in Open Source Software Communities: Motivations and Management
}

Dr Zilia Iskoujina ${ }^{1}$ and Professor Joanne Roberts ${ }^{2}$

${ }^{1}$ Senior Lecturer, Lord Ashcroft International Business School, Anglia Ruskin University, Cambridge. UK

${ }^{2}$ Professor of Arts and Cultural Management, Winchester School of Art, University of Southampton, Winchester. UK

\section{Structured Abstract:}

Purpose: This article seeks to add to understandings of knowledge sharing in online communities through an investigation of the relationship between individual participant's motivations and management in Open Source Software (OSS) communities. Drawing on a review of literature concerning knowledge sharing in organisations, the factors that motivate participants to share their knowledge in OSS communities, and the management of such communities, it is hypothesised that the quality of management influences the extent to which the motivations of members actually result in knowledge sharing.

Methodology: To test the hypothesis, quantitative data were collected through an online questionnaire survey of OSS web developers with the aim of gathering respondents' opinions concerning knowledge sharing, motivations to share knowledge, and satisfaction with the management of OSS projects. Factor analysis, descriptive analysis, correlation analysis, and regression analysis were employed to explore the survey data.

Findings: The analysis of the data reveals that the individual participant's satisfaction with the management of an OSS project is an important factor influencing the extent of their personal contribution to a community.

Originality: Little attention has been devoted to understanding the impact of management in OSS communities. Focused on OSS developers specialising in web development, the findings of this article offer an important original contribution to understanding the connections between individual members' satisfaction with management and their motivations to contribute to an OSS project. The findings reveal that motivations to share knowledge in online communities are influenced by the quality of management. Consequently, the findings suggest that appropriate management can enhance knowledge sharing in OSS projects and online communities, and organisations more generally.

Keywords: knowledge sharing, knowledge management, open source software communities, open source software projects, online communities, management

Article Classification: Research paper

\section{Acknowledgments:}

The authors would like to thank Dr Nick Drydakis for advice on the presentation of the quantitative data and the anonymous reviewers for their insightful comments and helpful suggestions. In addition, the authors gratefully acknowledge Durham University for the doctoral scholarships from Ustinov College and Durham University Business School, which made possible the empirical research from which this article draws.

\section{Biographical Details:}


Zilia Iskoujina is Senior Lecturer in the Lord Ashcroft International Business School, Anglia Ruskin University, UK. She gained her doctorate on 'Knowledge Sharing in Virtual Organisations: The Case of Open Source Software Communities' at Durham University Business School. She has held a postdoctoral post at the $£ 12.6$ million RCUK funded Research Hub for Inclusion through the Digital Economy (SiDE) at Newcastle University. She has been a content analyst for the Journal of Management Studies and a consultant researcher on the ESRC project entitled 'Evaluation of Doctoral Programme Accreditations' at Durham University.

Joanne Roberts is Professor in Arts and Cultural Management at Winchester School of Art, University of Southampton, UK. She has held posts in the business schools of Newcastle, Durham, and Northumbria Universities, UK. Her research interests include the internationalization of knowledge-intensive services, knowledge transfer, innovation and creativity, and critical perspectives on knowledge in organization and economy. She is currently investigating knowledge and ignorance in the field of luxury. Joanne has published articles in a wide range of international journals, including the Journal of Knowledge Management, Journal of Management Studies, International Business Review, and, Research Policy. She is author of Multinational Business Services Firms (Ashgate, 1998), and A Very Short, Fairly Interesting and Reasonably Cheap Book about Knowledge Management (Sage, 2015). She is also co-editor of four books: Knowledge and Innovation in the New Service Economy, with A. Andersen, J. Howells, R. Hull and I. Miles (Edward Elgar, 2000); Living with Cyberspace, with J. Armitage (Berg, 2002); Community, Economic Creativity and Organization, with A. Amin (Oxford University Press, 2008); and, Critical Luxury Studies: Art, Design, Media, with John Armitage (Edinburgh University Press, forthcoming 2016). Additionally, Joanne is the co-founder and co-editor of the award-winning journal Critical Perspectives on International Business, and an editor of the journal Prometheus: Critical Studies in Innovation. 


\section{Knowledge Sharing in Open Source Software Communities: Motivations and Management}

\section{Introduction}

The effective management of knowledge is a primary concern for organisations seeking to compete in the contemporary economic environment (Grant, 1996). Consequently, knowledge management strategies have become widespread (Hislop, 2013; Davenport and Prusak, 1998; Nonaka and Takeuchi, 1995; inter alia). Knowledge management may be defined as 'any process or practice of creating, acquiring, capturing, sharing and using knowledge, wherever it resides, to enhance learning and performance in organisations' (Scarbrough et al., 1999, p. 1). Knowledge sharing is, then, central to knowledge management practices (Renzl, 2008; Cabrera and Cabrera, 2005). In the process of sharing, knowledge is not only distributed but also transformed in the act of articulation, interpretation, and absorption. Knowledge sharing therefore contributes to the creation of new knowledge (Nonaka and Takeuchi, 1995). Consequently, knowledge sharing has attracted significant research attention (Li et al., 2014; Faraj et al., 2011; Ruuska and Vartiainen, 2005; inter alia). Despite the benefits of sharing knowledge there are barriers that prevent its free flow, for example, within organisations individuals may have incentives to hoard or hide knowledge (Michailova and Husted, 2003; Connelly et al., 2012).

Open Source Software (OSS) communities have been identified as exemplars of knowledge sharing. In such knowledge-intensive non-commercial environments individuals appear to share their knowledge freely with other community members in order to develop new and improved software products (Rolandsson et al., 2011; von Krogh and von Hippel, 2003; Raymond, 1999; inter alia). OSS communities, in which the software source code is freely available to those who wish to collaborate to solve a particular programming problem, involve many participants interacting with each other online. Hence, OSS communities provide an excellent context within which to investigate knowledge sharing in online organisations.

The success of knowledge sharing in OSS communities is apparent in the development of OSS tools and utilities, including Linux Operating System, Apache HTTP Server, MySQL Database, PHP Web Development Language - known as the LAMP stack for web servers, and the Firefox web browser. These products compete with their commercial counterparts in software markets. The success of these communities gives rise to various questions including: How do they facilitate knowledge sharing? And, what can commercial organisations learn from them about knowledge sharing? Much research attention has focused on what motivates members to participate and share knowledge in online communities (Wasko and Faraj, 2000; Bergquist and Ljungberg, 2001; Maki-Komsi et al., 2005). Yet, little attention has been devoted to understanding how the management of such communities may influence members' willingness to participate and thereby share their knowledge. Consequently, through an empirical investigation of OSS developers specialising in web development this article explores both how the motivations of individual participants influence their level of knowledge sharing and how such motivations are affected by the quality of the OSS community's management.

The article begins by briefly reviewing the literature on knowledge sharing before focusing on the factors stimulating knowledge sharing in online communities. The management of OSS communities is briefly considered and it is hypothesised that the quality of management 
influences the extent to which the motivations of participants actually result in the sharing of knowledge. The research methods are then briefly elaborated before the findings are reported. The implications of the findings for knowledge sharing in OSS projects and online communities more generally are discussed and the limitations of the study are noted. The article ends with brief concluding comments, including directions for future research.

\section{Literature review: knowledge sharing in OSS communities}

\section{Knowledge sharing in organisations}

Knowledge is an important organisational resource (Grant, 1996). However, as Lauring and Selmer (2012) note, its links to social structures make it is difficult to manage. An appreciation of knowledge sharing in organisations requires an understanding of the nature of knowledge. In the organisational context, knowledge is often defined as the application and productive use of information. Yet, knowledge is more than information, since it involves an awareness or understanding gained through experience, familiarity or learning. At a personal level, knowledge requires a relation between the 'knowing self' and the external world. Knowing is an active process that is mediated, situated, provisional, pragmatic and contested (Blackler, 1995). It involves cognitive structures that can assimilate information and put it into a wider context, allowing actions to be undertaken from it (Howells and Roberts, 2000). Furthermore, in some instances and respects knowledge may be individually centred, while in others it may be collectively held (Spender, 1996). Indeed, knowledge may be held in sophisticated information and communications technology (ICT) facilitated knowledge repositories (Davenport and Prusak, 1998), embedded in the routines and practices of organisations (Nelson and Winter, 1982), or situated in the communities that form around specific organisational practices (Wenger et al., 2002).

Whether knowledge is tacit or explicit influences the ease with which it may be shared. Tacit knowledge is non-codified knowledge that is acquired via the informal take-up of learning behaviour and procedures (Howells, 1996); it is often referred to as know-how. Explicit knowledge may be transferred across time and space embodied in codified tangible forms, such as training and operations manuals, software, and patents. Through the process of codification, knowledge is reduced to information that can be transformed into knowledge by those individuals who have access to the appropriate code or framework of analysis. For the individual, it is necessary to make an initial irreversible investment to acquire the relevant code (Arrow, 1974). In a sense, 'knowledge is a retrieval structure: the agents possessing a certain type of knowledge can retrieve both information based on this knowledge and other, similar, pieces of knowledge' (Saviotti, 1998, p. 848). Importantly, such a retrieval structure may be made up of both explicit and tacit knowledge.

Knowledge is rarely completely codified. Even explicit codified knowledge must be tacitly understood (Polanyi, 1967). If a body of knowledge contains a significant tacit element, the exchange of the codified part alone may fail to facilitate successful knowledge sharing (Roberts 2001). Tacit knowledge is difficult to fully articulate and it is therefore more time consuming to acquire. Sharing such knowledge may involve a process of demonstration and learning by doing (Roberts 2000; Arrow, 1974). As a result, tacitness gives knowledge a sticky quality (Szulanski, 1996; von Hippel, 1994).

Whatever the nature of knowledge, an important determinant of successful knowledge sharing will be the capacities of the individuals involved in the process. The original possessor of the 
knowledge must be able to articulate the knowledge to facilitate its externalisation and the recipient must be able to internalise the knowledge, that is, they must have an appropriate level of absorptive capacity (Cohen and Levinthal, 1990).

Organisational knowledge sharing takes place at various levels, from the individual to the group and across departments and divisions (Ipe, 2003). Knowledge sharing also reaches across organisational boundaries. At each of these levels, the role of the individual is essential for knowledge ultimately resides with the individual (Polanyi, 1967). Moreover, as Nonaka and Takeuchi (1995) argue, individual knowledge sharing is central to the creative process. Consequently, the ability of an organisation's members to share knowledge influences the speed of new product development (Renzl, 2008), and ultimately has a significant impact on organisational performance. Understanding the dynamics of knowledge sharing at the level of the individual is therefore of central importance to the development of successful knowledge management strategies (Cabrera and Cabrera, 2005). Ipe (2003), for example, identifies four core factors influencing knowledge sharing among individuals, namely, the nature of knowledge, the motivations to share, the opportunities to share, and the culture of the work environment.

Knowledge sharing requires the active engagement of individuals in a process of interaction and learning (Roberts, 2000). Consequently, understanding what motivates individuals to participate in knowledge sharing will support the design of successful knowledge management strategies. Moreover, a collaborative culture and opportunities to share knowledge in the work environment will directly affect the individual's knowledge sharing activity. These conditions can be influences by management practices. A wide range of academic studies explores knowledge sharing in organisations. For instance, Witherspoon et al., (2013) investigates the antecedents of organisational knowledge sharing, Young (2014) examines knowledge sharing intention in knowledge management systems, and Amayah (2013) explores the determinants of knowledge sharing in a public sector organisation. Studies that include a focus on management and governance include Chuang et al.'s (2015) examination of factors influencing middle management employees' knowledge sharing intentions, and Huang et al.'s (2013) assessment of the mediating roles of motivation on knowledge governance mechanisms. More broadly, Cabrera and Cabrera (2005) identify the socio-psychological determinants of knowledge sharing, including social ties and shared language, trust, group identification, perceived cost, perceived rewards, self-efficacy, and expectations of reciprocity. Their findings suggest that people management practices focused on work design, staffing, training and development, performance appraisal, compensation, culture, and technology can support knowledge sharing (Cabrera and Cabrera, 2005).

Although much knowledge is shared between co-located individuals, it is increasingly the case that creative activity is geographically distributed, whether in the globally dispersed research and development units of large companies or in online communities (Amin and Roberts, 2008). Since the rise of the Internet, a growing number of online communities have emerged in which knowledge is created and shared by individuals working voluntarily in informal self-organising virtual structures (Roberts, 2014; Prasarnphanich and Wagner, 2011; Baytiyeh and Pfaffman, 2010). In online communities, codified knowledge is shared electronically. The codified knowledge of expert communities may be highly specialised and require a significant amount of individual tacit knowledge for it to be interpreted, absorbed, and employed by recipients. Understanding knowledge sharing in spatially dispersed communities in which individuals communicate with one another through frequent online communications is of growing importance. Based on an exploration of a distributed work 
environment, Maki-Komsi et al. (2005) suggest that factors contributing to successful knowledge sharing include: communication of the required information, support for informal learning based on colleagues' practical experiences, shared work practices within the team or community, right group membership, group members' attitudes towards knowledge sharing, openness towards knowledge sharing, feeling of community with remote colleagues, voluntary participation in the knowledge sharing activities, shared responsibility for sharing knowledge, agility of the tools in use, and good team leadership coordinating the communication. Additionally Faraj et al. (2011) argue that knowledge sharing in online communities is aided by the presence of the tensions among five resources: passion, time, ambiguous social identity, social disembodiment of ideas, and temporary convergence. The combinations of such resources reveal themselves in the strength of an individual's motivation to share knowledge.

\section{Motivations to share knowledge in OSS communities}

Ipe (2003) identifies internal and external factors that influence an individual's motivation to share knowledge. Internal factors include the perceived power attached to knowledge and reciprocity arising from sharing knowledge, and external factors relate to relationships with recipients and the rewards arising from sharing knowledge. Connected to these factors is the value of knowledge to the individual and to the organisation (Prasarnphanich and Wagner, 2011; Chang and Chuang, 2011; inter alia). Indeed, knowledge hoarding may result when exclusive access to certain knowledge gives individuals status within the organisation (Connelly et al., 2012; Michailova and Husted, 2003). The value of knowledge in relation to competition between organisational members also raises the issue of trust between workers and management. For instance, Renzl (2008) finds that trust in management encourages knowledge sharing by reducing an individual's fear of losing their unique value, while Connelly et al. (2012) find that employees do not share knowledge with those they distrust.

These findings are equally relevant to knowledge sharing in online communities. An additional consideration for such communities is the availability of an appropriate information technology (IT) infrastructure. Distributed community members must be able to connect to and use electronic networks if they are to share knowledge (Huysman and Wulf, 2006). Hence, their motivations are only effective when technological tools enable the communication that is required to share knowledge. The technological tools available to members of an OSS community are now standardised involving email and online forums as well as databases that retain earlier electronic exchanges and versions of the software code at various stages of its development. Importantly, such infrastructure requires appropriate management to facilitate the smooth, reliable, and ongoing communications between community members.

Individual members' contributions to an online community are not always an addition to the community's knowledge base. However, the exchanges between members often lead to creative engagement and in this way to the collaborative development of new knowledge. In an OSS community, this new knowledge takes the form of a development in the software at the centre of a project. An appreciation of what motivates individuals to contribute to such communities provides a basis for understanding knowledge sharing behaviour and offers insights into how to stimulate more effective and frequent knowledge sharing with positive outcomes for creativity in online communities and organisations more broadly (Chiu et al., 2006). 
Much research has focused on the motivations underpinning knowledge sharing in OSS communities. Lead-users are particularly active in contributing to software developments and thereby encouraging knowledge sharing because of their desire to influence product development (Jeppesen and Laursen, 2009). Bergquist and Ljungberg (2001) draw comparisons between knowledge sharing in online communities and in academia where individuals share knowledge, not only for altruistic reasons, but also because it is an accepted requirement of career progression within this field. Based on the findings of a study of three Usenet technical communities, Wasko and Faraj (2000) argue that people collaborate and shared knowledge in the expectation of tangible and intangible returns. Tangible benefits include, for instance, an answer to a technical problem, and intangible reasons comprise, meeting like-minded individuals, learning from solutions offered, peer recognition, a moral obligation to help others in a common technical community, maintaining standards, and spreading ideas.

Bonaccorsi and Rossi (2003) and Ulhoi (2004) have identified five broad types of motives for sharing knowledge in OSS communities, namely, economic, psychological, social, intellectual, and technological. Economic drivers can relate to monetary rewards following the completion of a project or gaining a reputation among peers with future career benefits. Improved value of skills, feeling of solidarity, feeling of altruism and efficiency, and reputation are among the psychological drivers. Social drivers include social prestige, expectation of reciprocity, fun of programming, sense of belonging to the community, and the fight against proprietary software. Aesthetic qualities, individual needs, and learning opportunity are intellectual drivers. Working with "cutting-edge technology" is a technological driver. More specifically, Aalbers (2004) identifies three core motives for sharing knowledge in OSS communities, namely, self-enriching, group-enriching, and knowledge-enriching. Although many studies identify the two key motivations as intrinsic and extrinsic (Mikkonen et al., 2007), beyond this there is a general lack of consensus on the core factors influencing motivations for knowledge sharing in online communities.

An extensive review of the available literature undertaken for this research suggest that the motivations underpinning knowledge sharing in OSS communities can be grouped into seven core types, namely, hobbies, philosophical factors, accomplishments, altruism, network opportunities, personal needs and main work needs. Table 1 summarises the literature on the motivations driving knowledge sharing in OSS communities. However, motivations alone do not ensure successful knowledge sharing. Management can have an important impact facilitating an organisational context that is conducive to knowledge sharing, for example, by providing appropriate rewards, encouraging a trusting environment, providing robust technology, and good leadership. Consequently, attention now turns to the role of management in online communities and OSS projects to assess its influence on knowledge sharing.

Insert Table 1 about here

\section{Management in OSS communities}

As online communities grow and mature, they required systems of coordination just like any other organisation (Chua and Yeow, 2010). Contrary to popular perceptions of selfmanagement, the large OSS communities have highly developed systems of coordination and 
control - or management - centred on core and peripheral teams with frequent interaction between the two. The coordination structure and roles in OSS communities have been traced in a number of studies (Chua and Yeow, 2010; Jensen and Scacchi, 2007; inter alia). The findings of such research suggest a sophisticated division of labour with positions of authority determined by competence. According to Schmidt and Porter (2001) in OSS communities, core developers are responsible for activities such as the inspection of the software architectural integrity, fixing mistakes and track day-to-day progress, whereas periphery developers test and debug the software released periodically. Indeed, Madanmohan and Navelkar (2002) describe the following six roles with specific knowledge management responsibilities in online communities: Core Organiser, who organises the community, initiates discussions and groups formations; Expert, who shares her/his tacit knowledge; Problem poser, who brings problems and poses queries; Implementer/Bug reporter, who establishes the practical validity of the suggestions made, and reports limitations/bugs; Integrator, who brings together several rules and/or suggestions, and builds the project's taxonomy/manual; and, finally, Institutionaliser, who push for standardisation and regulatory support. Importantly, unlike traditional hierarchical organisations where roles and rewards are formally fixed, in online communities role behaviour is flexible (Madanmohan and Navelkar, 2002), allowing talented members of the periphery to move easily into the core.

The distribution of responsibilities in OSS projects can be depicted in the form of an "onion" with passive users and/or observers at the outer layer, and active users, developers, project managers and community managers being progressively closer to the centre and, core developers at the very heart of the community (Jensen and Scacchi, 2007). Four methods of role acquisition can be identified in OSS communities: implicitly by performing a task; earned and granted by a body of authority; elected to a position by the community or a subcommittee; and, appointment by an individual or body of authority (Jensen and Scacchi, 2007).

According to Raymond (1999), any software project management has five functions: to identify aims/goals and coordinate activity so that everybody keeps progressing in the same direction, to monitor to ensure that details are not skipped, to motivate people to do boring but necessary work, to organise contributors to maximise productivity, and to secure the resources necessary for the project. The success of OSS projects requires not only the effective management of people and the securing resources, but as Asklund and Bendix (2001) note, tools and processes must also be managed. Technical tools, such as servers, are vital for OSS development because the codes of all software versions and bug fixes must be stored. The importance of technological tools and software platforms for interaction in OSS communities necessitates active management (Metiu and Kogut, 2001). Even when technology is managed well its limitations in terms of knowledge sharing must recognised. For instance, excellent online communication tools cannot alone facilitate the transmission of tacit knowledge (Roberts, 2000).

Given the voluntary nature of contributions to OSS projects, the social aspects of the community can have an important impact on members' motivations to participate and share knowledge (Bonaccorsi and Rossi, 2003; Ulhoi, 2004). Consequently, creating a socially rewarding atmosphere that is conducive to knowledge sharing among contributors is an important task for the management of geographically dispersed online communities.

The management of OSS communities is essential to coordinate the collaborative efforts of geographically dispersed voluntary contributors to achieve one goal efficiently. Yet, few 
studies of OSS communities consider how members' satisfaction with management influences the success of a project and the motivations of individuals to share their knowledge. Nevertheless, Agterberg et al. (2010) suggest that the environments in which they occur influence community members' knowledge sharing activities. Management can therefore influence knowledge sharing by exerting control over community content and connections through designing and maintaining an appropriate organisational infrastructure (Agterberg et al., 2010). Members' satisfaction with management in online communities can be influenced by the attributes of the people involved and levels of trust present in the community (Staples and Ratnasingham, 1998; Shin, 2004). Nevertheless, management in an OSS project can slow software developments and become a bottleneck if it delays the dissemination and use of a newly developed application (Asklund and Bendix, 2001).

The contributions of individual members are important to the success of OSS communities. As extant research reveals, members' motivations are underpinned by a variety of factors (Table 1). Yet, highly motivated members alone do not ensure a community's success. Other factors are required to enable members' motivations to be fully harnessed to accomplish the community's goals. In particular, the appropriate management of people and resources within an OSS community is vital to promote the efficient organisation of community members' efforts and to ensure that members' motivations to share knowledge are realised. Without appropriate management members' motivations can be dampened by, for example, the frustrations that can be caused by a poor communication infrastructure, inadequate technological support, lack of reward in the form of recognition, or a negative, distrustful social culture. Hence, the management of an OSS community can influence its members' motivations to share knowledge. Although motivations to contribute to OSS communities derive from the individual's characteristics, these motivations are moderated by the quality of the management. It can therefore be hypothesised that: The higher the quality of management the stronger will be the individual's motivations to share knowledge in OSS projects.

\section{Research methods}

To test the hypothesis outlined in the previous section, it was necessary to gather data on the relevant variables, namely members' satisfaction with management as an indicator of the quality of management, the strength of individual's motivations and the extent to which individuals share knowledge in the OSS community. The research adopted a quantitative approach with data collected through the use of an online questionnaire survey (see Appendix 1). The questionnaire design drew on previous studies identified through the review of literature. Following a pilot study with ten OSS developers, the questionnaire was reviewed and revised to correct the weaknesses identified prior to its widespread distribution. Although different from the real respondents, the participants in the pilot study were comparable to members of the population from which the real sample was drawn (Bryman and Bell, 2003). The main survey employed a dedicated webpage through which the respondents' data was automatically compiled into a database. The data collection process was designed to maintain respondents' anonymity in line with ethical research practices. During the period from $21^{\text {st }}$ May 2007 to $31^{\text {st }}$ July 2007, 275 email exchanges were undertaken with individuals, communities (through online discussion boards/forums), and groups of people related to OSS development to solicit participation in the survey. By the end of July 2007, 142 respondents had completed the questionnaire. Due to significant amounts of missing data, five responses were excluded, giving a total of 137 responses available for the data analysis. 
Although the scale of the OSS community is unknown, an indication of its size was gained from SourceForge.net, which is one of the world's largest OSS development websites. In the summer of 2007, it hosted more than 142 thousands projects and had nearly 1.5 million registered users. Given the lack of complete information on the total population of OSS community members, it was not possible to calculate the appropriate sample size as recommended by Sekaran (2003). However, Roscoe (1975) suggests that a sample size larger than 30 and less than 500 is appropriate for most research and that in multivariate research the sample size preferably should be 10 times as large as the number of variables. A frequently used formula to calculate sample size is $\mathrm{N}>50+8 \mathrm{~m}$, where ' $\mathrm{m}$ ' is the number of independent variables (Tabachnick and Fidell, 2007; Pallant, 2007). This study sought to maximise the sample size and the number of responses obtained meets the parameters necessary to ensure reliable results.

Factor analysis was implemented to identify the variables required to test the hypothesis, and to checking the data for reliability. Variables were identified by grouping appropriate questions together from the questionnaire as shown in Table 2. The Cronbach's Alpha for most variables considered in this study were higher than 0.8 and a few of them were higher than 0.7 (Table 2). Additionally the Component Matrix was $>0.5$ indicating high internal consistency and reliability (Sekaran, 2003).

\section{Insert Table 2 about here}

An independent variable 'KNOWLEDGE SHARING', was created by employing three questions from the questionnaire that were connected with one meaning - the respondent's view of their knowledge sharing in OSS communities. These questions concerned the following: 1) the individuals' frequency of communication with members of the community (FREQ COM); 2) the hours per week spend sharing knowledge in the OSS project (HOURS PER WK); and, 3) the percentage of the respondents' participation related to project development in the OSS community (\% PART PROJ DEV). Factor analysis revealed that the cumulative percentage of variance accounted for by all these factors is equal to $65 \%$. Hence, through factor analysis it was possible to employ these three questions to construct the variable 'KNOWLEDGE SHARING', with a Cronbach's Alpha equal to .818.

As an indicator of the quality of management, a moderating variable 'SATISFACTION WITH MANAGEMENT' was created by employing a set of six questions concerning respondents' view of management to produce one variable through factor analysis (see Table 2). Drawing from an analysis of the relevant literature (see for example, Amaratunga and Baldry, 2002; Macbryde and Mendibil, 2003; and Mikkonen et al., 2007) as well as discussions with individuals involved in OSS development projects, the questions employed a 5 -point interval scale labelled either from 'very satisfied' to 'very dissatisfied' or from 5 'strongly agree' to 1 'strongly disagree'. The Cronbach's Alpha for the moderating variable constructed through this process was equal to .862 .

A dependent variable 'MOTIVATIONS' was created by employing a 5-point Likert-type scale (5 - 'strongly agree' to 1 -'strongly disagree') in a set of questions designed to assess the strength of each motivation identified from the literature (see Table 1). By a dependent variable 'MOTIVATIONS' we mean a set of seven variables - "Hobby", "Altruism", "Accomplishment", "Philosophical Factors", "Network Opportunities", "Personal Needs", 
and "Main Work Needs" (Table 2). It is therefore possible to analyse the importance of different types of motivations for knowledge sharing in relation to levels of satisfaction with management. The Cronbach's Alpha for the various components of 'MOTIVATIONS' ranged from $.721-.878$.

Following an analysis of the descriptive data, correlation analysis was employed to explore the relationship between the variables in the hypothesis. The analysis was extended through the application of regression analysis. The data analysis was facilitated by the use of SPSS (Statistical Package for the Social Sciences), with guidance from Pallant (2007) and Hair et al., (2007).

\section{Results}

\section{Descriptive data analysis}

The geographical distribution of the questionnaire respondents centred predominantly on the advanced western nations. The largest portion of the respondents derived from the USA (35.77\%), with the UK being the second largest source $(24.82 \%)$, of the remaining respondents $21.90 \%$ were from other European countries, 3.65\% were from Australia, 2.19\% were from New Zealand, and $2.92 \%$ were from Canada. The rest of the world accounted for the remaining $8.75 \%$ of respondents.

Almost $98 \%$ of the questionnaire respondents were male and the majority of these were under 30 years of age. Respondents were distributed among age ranges as follows: $51.82 \%$ aged 20$29 ; 22.63 \%$ aged $30-39 ; 8.76 \%$ aged $40-49 ; 2.19 \%$ aged $50-59$; less than $1 \%$ aged $60-69$; and, $6.57 \%$ aged under 19 . Over $80 \%$ of the respondents were younger than 40 . Combining the geographical location and age of the respondents, it is interesting to note that countries other than the UK and USA, had a higher proportion of younger contributors. The sample of respondents from the USA was characterised by greater age diversity than those of other countries. The primary occupation of the majority of the respondents was either an IT employee $(35.48 \%)$ or IT - self-employed (32.26\%). Of the remaining respondents, $18.06 \%$ were students, $6.45 \%$ were in employment other than IT, and $7.75 \%$ were retired or engaged in other activities. Although the data confirmed the existence of a hierarchy within the OSS community, members predominantly engage with their peers ( $47.3 \%$ of the respondents), with only $36.94 \%$ of the respondents making contact with forum/project moderators, and $15.77 \%$ of the respondents making contact with top management teams.

To summarise, the questionnaire respondents were predominantly young males with extensive IT knowledge and they derived largely from English speaking countries, especially the USA and the UK. These characteristics conform to those of OSS communities members identified in other studies (see for example, Jensen \& Scacchi, 2007).

\section{Correlation analysis}

Pearson's correlation analysis was employed to investigate the strength of relationships between knowledge sharing, motivations and satisfaction with management in OSS communities. As evident from Table 3, these variables are positively correlated. Most importantly, the correlation analysis demonstrates that management has positive relationships with five out of seven motivations: philosophical factors $\left(.305^{* *}\right)$, accomplishment $\left(.262^{* *}\right)$, altruism $\left(.367^{* *}\right)$, network opportunities $\left(.310^{* *}\right)$, personal needs $\left(.393^{* *}\right)$. These results 
suggest that management can positively influences the motivations of OSS community members. Additionally, satisfaction with management is positively correlated with knowledge sharing $\left(.213^{*}\right)$, suggesting that knowledge sharing is associated with the successful management practices. Furthermore, individual sources of motivation have positive and often significant association with each other (Table 3). For instance, accomplishment as a motivation has positive relationships with other motivations such as hobby $\left(.218^{*}\right)$ and philosophical factors $\left(.295^{* *}\right)$, while altruism has positive relations with philosophical factors $\left(.380^{* *}\right)$ and accomplishment $\left(.758^{* *}\right)$, and personal needs have positive relations with philosophical factors $\left(.623^{* *}\right)$, accomplishment $\left(.504^{* *}\right)$, altruism $\left(.555^{* *}\right)$, and network opportunities $(.532 * *)$.

Insert Table 3 about here

\section{Regression analysis}

To investigate further the relationship between knowledge sharing, motivations and satisfaction with management in OSS communities hierarchical multiple regression analysis was undertaken to explore the multiple relationships between the variables (Table 4a-c). In this analysis, the independent variable (predictor), which needs to be controlled for, was entered into the regression in the first stage. The moderating variable, whose relationship was to be examined, was entered in the second stage. The analyses confirmed the reliability of the data, for instance, the indicator of the significant $F$ showed very low levels (Table $4 b$ ) (Pallant, 2007). The results of the multiple regression analysis show that satisfaction with management plays a significant role influencing the strength of contributor's motivations. At each stage in the hierarchical multiple regression analysis, an additional term is added in order to calculate the change in $\mathrm{R}^{2}$. A hypothesis is tested based on whether the change in $\mathrm{R}^{2}$ is significantly different from zero. In our analysis, $\mathrm{R}^{2}$ is different from zero and the change in $\mathrm{R}^{2}$ from Model 1 to Model 2 is not large, which means that the value is significant (Table $4 \mathrm{a}$ b).

Interestingly, hobby and main work needs do not show a significant relationships with knowledge sharing and satisfaction with management $(b=.081, t=.776$, ns) and $(b=.164$, $\mathrm{t}=1.582$, ns) respectively (Table $4 \mathrm{c}$ ). These results may be explained by the particular attitudes of individuals whose main motivations for contributing to the OSS community are based on a hobby or main work needs, in the sense that these individuals may be less sensitive to the quality of management; they will contribute even when they are less satisfied with management than members whose other motivations are stronger. In contrast, all other motivations were found to be dependent on satisfaction with management: altruism $(b=.339$, $\left.\mathrm{t}=3.566, \mathrm{p}<.001^{* *}\right)$, personal needs $\left(\mathrm{b}=.380, \mathrm{t}=4.298, \mathrm{p}<.000^{* * *}\right)$, philosophical factors $\left(\mathrm{b}=.301, \mathrm{t}=3.097, \mathrm{p}<.003^{* *}\right)$, accomplishment $\left(\mathrm{b}=.251, \mathrm{t}=2.529, \mathrm{p}<.013^{*}\right)$, and network opportunities $(\mathrm{b}=.310, \mathrm{t}=3.154, \mathrm{p}<.002 * *)$ (Table $4 \mathrm{c})$. Additional analysis was undertaken to explore the influence of respondents' age on the connection between knowledge sharing, motivations and satisfaction with management. Two age ranges - one below 30 years and the other above 30 years - were analysed. The results for both age ranges were consistent with those of the main analysis indicating that motivations to share knowledge did not vary with age. 
The data analysis suggests that satisfaction with management plays an essential role increasing the strength of OSS contributor's motivations. Consequently, satisfaction with management influences the level of knowledge sharing in OSS communities as a whole. Only hobby and main work needs do not show a significant relationship with satisfaction with management.

Insert Table 4 about here

\section{Discussion}

The findings support the view that the management of geographically dispersed online communities plays a crucial role in creating an environment for OSS community members that is conducive to knowledge sharing. Good management therefore contributes to the success of the OSS communities. In particular, members' satisfaction with management influences the realisation of individual motivations to share knowledge. The results of this study supports the current academic literature (Metiu and Kogut, 2001; Asklund and Bendix, 2001; Van Den Hooff and Huysman, 2009; inter alia), by showing the importance of wellorganised management for successful knowledge sharing between OSS community members. Moreover, the findings confirm the hypothesis identified earlier by suggest that the quality of management in OSS communities is an essential factor strengthening an individual's motivations to share knowledge in OSS projects.

Clearly, the activities of the leaders and managers of OSS communities, and managers of organisations in general, can play an important role supporting knowledge sharing processes within their communities and organisations. For instance, by promoting an amenable environment, managers may facilitate the full realisation of personal motivations and thereby enhance knowledge sharing. By paying attention to the factors that motive community members, and aligning their management practices to take account of such motivations, managers can support higher levels of knowledge sharing, thereby increasing the speed of new products and services development (Renzl, 2008).

However, the findings of this study suggest that the factors that motivate community members differ and that different motivations have different sensitivities to the quality if management. Hence, where OSS community members' motivations are based on a hobby or main work needs, they are less sensitive to the quality of management when compared to others whose motivations derive from other sources. OSS community managers would benefit from understanding the source of motivations of their members, as this will allow scarce managerial resources to be directed towards supporting those members whose motivations are more likely to be dampened by low levels of satisfaction with management.

Although motivations to contribute in OSS development are important for knowledge sharing, as Agterberg et al. (2010) found in their study of geographically distributed inter organisational networks, organisational factors, including management, are the key to keeping online communities alive, productive, and looking forward to further innovations. While OSS communities may emerge spontaneously from a mutual interest in a particular programming problem, for such communities to develop and thrive over time management systems are necessary to support individual participants and ensure that their levels of motivations are sustained over time. Leaders and managers of OSS communities can do much to encourage knowledge sharing and to strengthen the individual's level of motivation. As in the non- 
virtual world, managers of OSS communities can promote knowledge sharing through the development of favourable technological, cultural, and organisational environments within which community members can develop their own knowledge through sharing and interacting with others in the process of OSS development. These insights have relevance beyond the OSS community as organisations of all sorts are seeking to harness the voluntary contributions of workers, supplier, and customers to support their knowledge sharing strategies both in online and real world communities

Knowledge sharing is one of the most challenging issues in the management of knowledge. Yet in OSS communities, individual members need to share their knowledge in order to engage in the activities of the community. By investigating knowledge sharing and how satisfaction with management influences the motivations to share knowledge in the specific example of OSS communities, the findings of this study provide an original contribute to the current academic literature on knowledge management and, in particular, the connections between individual members' satisfaction with management and motivations to share knowledge in the OSS community. This adds to knowledge of the complexity of motivations and suggests that appropriate management can enhance knowledge sharing in OSS communities.

Nevertheless, the research has some limitations. According to Podsakoff et al. (2003), method biases are one of the main sources of measurement error. Potential sources of method biases are common rate effects, item characteristic effects, item context effects and measurement context effects. The online questionnaire was designed with a careful consideration of problematic factors such as obtaining measures of the predictor and criterion variables from different sources, protecting respondent anonymity to reduce evaluation apprehension, counterbalancing the question order and improving scale items. However, there still can be a bias of 'measurement context effects' present in the nature of the work which corresponds to any artifactual covariation formed from the context, where the measures are obtained (Podsakoff et al., 2003).

In addition, this research was conducted via a cross-sectional study, which can be considered as one of the potential biases. According to Bozionelos (2002), causal path modelling is a useful technique for the well-designed description of the relationships between variables. Such modelling was used in this research during the regression analysis. However, these types of design do not allow "causality assertions", because "causality in cross-sectional research can be only speculated and tentatively accepted; and needs to be further substantiated with utilization of the other research designs" (Bozionelos, 2002, p. 7). According to Bozionelos (2002, p. 7), when cross-sectional designs are "utilized certainty on causality is seriously compromised, regardless of the way authors choose to present their findings".

There are also limitations resulting from the size of the sample used in this research. Even though the sample size in the quantitative data collection can be regarded as reliable, the findings would be strengthened if there were more observations. For future research the sample size could be improved by attending major OSS conferences and distributing the questionnaire for completion to the conference delegates. Finally, because the empirical data was collected in 2007, it is important to recognise that the OSS community and its members may have changed thereby undermining the relevance of the findings presented here. Nevertheless, the analysis of the data has produced findings that are consistent with recent studies considered in the review of literature. 


\section{Conclusions}

Understanding the dynamics of knowledge sharing is an issue of central concern to managers of knowledge intensive organisations including online communities (Faraj et al., 2011; Ruuska and Vartiainen, 2005; Van Den Hooff and Huysman, 2009; inter alia). How the management of online communities can influence the knowledge sharing activities of members is poorly appreciated (Metiu and Kogut, 2001; Asklund and Bendix, 2001; Van Den Hooff and Huysman, 2009). Consequently, this article has sought to shed light on the relationship between the quality of OSS community management, individual members' various motivations, and levels of knowledge sharing.

Although there has been much research directed towards identifying the factors that motivate OSS community members to engage in knowledge sharing, little attention has been devoted to understanding how management may influence the motivations identified. The findings of this empirical study suggest that the members' motivations do affect the level of knowledge sharing in OSS communities, but that members' satisfaction with management is also important in determining the level of knowledge sharing. From the perspective of the individuals surveyed, the analysis suggests that successful knowledge sharing is facilitated by high levels of satisfaction with OSS community management in combination with individuals' motivations to share knowledge, rather than only individuals' motivations to share knowledge. Consequently, knowledge sharing in OSS communities is facilitated through the appropriate management of members and resources, including processes and IT infrastructures.

The findings of this study reveal that there are differences between community members according to the source of their motivations and such differences influence the extent to which the quality of management can enhance levels of knowledge sharing. Recognising and adapting to the variations in members' sources of motivation to share knowledge is something that would benefit both online voluntary communities and commercial organisations. Understanding the differences in the sources of members' motivations, and how management practices need to be adapted to such differences would be valuable. Furthermore, there are many different types of OSS communities, large well-known ones such as PHP, MySQL and Apache and small recently created ones. Understanding how managerial requirements vary according to the size and stage of development of the OSS community would also be useful. This article has provided fresh insights into the motivations stimulating knowledge sharing in OSS web development projects and the impact of management on these motivations. Nevertheless, there is scope for further research to uncover the full complexity of knowledge sharing deriving from voluntary contributions in online communities and organisations more broadly.

\section{References}

Aalbers, M. (2004), "Motivation for Participation in an Open Source Software Community", available at http://download.blender.org/documentation/bc2004/Martine_Aalbers/resultssummary.pdf (accessed 12 March 2015).

Agterberg, M., Van Den Hooff, B., Huysman, M. and Soekijad, M. (2010), "Keeping the Wheels Turning: The Dynamics of Managing Networks of Practice", Journal of Management Studies, Vol. 47, pp. 85-108. 
Amaratunga, D. and Baldry, D. (2002), "Performance Measurement in Facilities Management and Its Relationships with Management Theory and Motivation", Facilities, Vol. 20 No. 5/6, pp. $217-223$.

Amayah, A.T. (2013), "Determinants of Knowledge Sharing in a Public Organization", Journal of Knowledge Management, Vol. 17 No. 3, pp. 454-471.

Amin, A. and Roberts. J. (2008), "Knowing in Action: Beyond Communities of Practice", Research Policy, Vol. 37 No. 2, pp. 353-369.

Arrow, K.J. (1974), The Limits of Organization, W. W. Norton and Company, New York and London.

Asklund, U. and Bendix, L. (2001), "Configuration Management for Open Source Software”, available at

http://citeseerx.ist.psu.edu/viewdoc/download?doi=10.1.1.20.9193\&rep=rep1\&type $=p$ $d f$ (accessed 10 March 2015).

Baytiyeh, H. and Pfaffman, J. (2010), "Open Source Software: A community of Altruists", Computers in Human Behavior, Vol. 26, pp. 1345-1354.

Bergquist, M. and Ljungberg, J. (2001), "The Power of Gifts: Organizing Social Relationships in Open Source Communities", Information Systems Journal, Vol. 11 No. 4, pp. 305-320.

Blackler, F. (1995), "Knowledge, Knowledge Work and Organizations: An Overview and Interpretation", Organization Studies, Vol. 16 No. 6, pp. 1021-1046.

Bonaccorsi, A. and Rossi, C. (2003), "Why Open Source software may succeed," Research Policy, Vol. 32 No. 7, pp. 1243-1258.

Bozionelos, N. (2002), "Causal Path Modelling: What It Does and What It Does Not Tell Us", Career Development International, Vol. 8, pp. 5-11.

Bryman, A. and Bell, E. (2003), Business Research Methods, Oxford University Press, Oxford, UK.

Cabrera, E. F. and Cabrera, A. (2005), "Fostering Knowledge Sharing through People Management Practices", International Journal of Human Resource Management, Vol. 6, pp. 720-735.

Chang, H. H. and Chuang, S.-S. (2011), "Social Capital and Individual Motivations on Knowledge Sharing: Participant Involvement as a Moderator", Information and Management, Vol. 48, pp. 9-18.

Chiu, C.-M., Hsu, M.-H. and Wang, E. T. G. (2006), "Understanding Knowledge Sharing in Virtual Communities: An Integration of Social Capital and Social Cognitive Theories", Decision Support Systems, Vol. 42, pp. 1872-1888.

Chua, C. E. H. and Yeow, A. Y. K. (2010), "Artifacts, Actors, and Interactions in the CrossProject Coordination Practices of Open-Source Communities", Journal of the Association for Information Systems, Vol. 11, pp. 838-867.

Chuang, S.S., Chen, K.S. and Tsai, M.T. (2015), "Exploring the Antecedents that Influence Middle Management Employees' Knowledge-Sharing Intentions in the Context of Total Quality Management Implementations", Total Quality Management and Business Excellence, Vol. 26 No. 1-2, pp. 108-122.

Cohen, W. M. and Levinthal, D. A. (1990), "Absorptive capacity: A new perspective on learning and innovation", Administrative Science Quarterly, Vol. 35 No. 1, pp. 128-152.

Connelly, C. E., Zweig, D., Webster, J. and Trougakos, J. P. (2012), "Knowledge Hiding in Organizations", Journal of Organizational Behavior, Vol. 33, pp. 64-88.

Davenport, T. H. and Prusak, L. (2000), Working Knowledge. How Organisations Manage What They Know, Harvard Business School, Boston, USA.

Faraj, S., Jarvenpaa, S. L. and Majchrzak, A. (2011), "Knowledge Collaboration in Online Communities”, Organization Science, Vol. 22, pp. 1224-1239. 
Faraj, S. and Wasko, M. M. (2001), "The Web of Knowledge: An Investigation of Knowledge Exchange in Networks of Practice", available at http://ifipwg213.org/system/files/Farajwasko.pdf (accessed 11 March 2015).

Grant, R. M. (1996), “Toward a Knowledge-Based Theory of the Firm”, Strategic Management Journal, Vol. 17, pp. 109-122.

Hair, J. F., Black, W. C., Babin, B. J., Anderson, R. E. and Tatham, R. L. (2007), Multivariate Data Analysis, Prentice - Hall International Inc., New Jersey, USA.

Hars, A. and Ou, S. (2002), "Working for Free? Motivations for Participating in Open-Source Projects", International Journal of Electronic Commerce, Vol. 6, pp. 25 - 39.

Hertel, G., Niedner, S. and Herrmann, S. (2003), "Motivation of Software Developers in Open Source Projects: An Internet-Based Survey of Contributors to the Linux Kernel", Research Policy, Vol. 32, pp. 1159 - 1177.

Hislop, D. (2013), Knowledge Management in Organizations. A Critical Introduction, $3^{\text {rd }}$ Edition, Oxford University Press, Oxford, UK.

Howells, J. (1996), “Tacit Knowledge, Innovation and Technology Transfer”, Technology Analysis and Strategic Management, Vol. 8 No. 2, pp. 91-106.

Howells, J. and Roberts, J. (2000), "From Innovation Systems to Knowledge Systems", Prometheus: Critical Studies in Innovation, Vol. 18 No. 1, pp. 17-31.

Huang, M.C., Chiu, Y.P. and Lu, T.C. (2013), "Knowledge Governance Mechanisms and Repatriate's Knowledge Sharing: The Mediating Roles of Motivation and Opportunity", Journal of Knowledge Management, Vol. 17 No. 5, pp. 677-694.

Huysman, M. and Wulf, V. (2006), "IT to Support Knowledge Sharing in Communities, Towards a Social Capital Analysis", Journal of Information Technology, Vol. 21, pp. 40-51.

Ipe, M. (2003), "Knowledge Sharing in Organizations: A Conceptual Framework”, Human Resource Development Review, Vol. 2 No. 4, pp. 337-359.

Jensen, C. and Scacchi, W. (2007), "Role Migration and Advancement Processes in OSSD Projects: A Comparative Case Study", Free / Open Source Research Community, available at http://www.ics.uci.edu/ wscacchi/Papers/New/Jensen-Scacchi-ICSE2007.pdf (accessed 10 March 2015).

Jeppesen, L. B. and Laursen, K. (2009), "The Role of Lead Users in Knowledge Sharing”, Research Policy, Vol. 38, pp. 1582-1589.

Lakhani, K. R. and Von Hippel, E. (2002), "How Open Source Software Works: "Free” Userto-User Assistance", Research Policy, Vol. 32, No. 6, pp. 923-943.

Lauring, J. and Selmer, J. (2012), "Knowledge Sharing in Diverse Organisations", Human Resource Management Journal, Vol. 22, pp. 89-105.

Li, X., Roberts, J., Yan, Y. and Tan, H. (2014), "Knowledge sharing in China-UK higher education alliances", International Business Review, Vol. 23 No. 2, pp. 343-355.

Macbryde, J. and Mendibil, K. (2003), "Designing Performance Measurement Systems for Teams: Theory and Practice", Management Decision, Vol. 41 No. 8, pp. 722-733.

Madanmohan, T. R. and Navelkar, S. (2002), "Roles and Knowledge Management in Online Technology Communities: An Ethnography Study", Roles and Knowledge Management in Online Technology Communities: An Ethnography Study”, IIM Bangalore Research Paper No. 19, available at SSRN: http://ssrn.com/abstract=2156757 (accessed 10 March 2015).

Maki-Komsi, S., Poyry, P. and Ropo, E. (2005), "Learning and Knowledge Building in Distributed Work Environment", The Electronic Journal for Virtual Organizations and Networks (eJOV), Vol. 7, pp. 34-55.

Metiu, A. and Kogut, B. (2001), "Distributed Knowledge and the Global Organization of Software Development", 
http://citeseerx.ist.psu.edu/viewdoc/download?doi=10.1.1.13.4724\&rep=rep1\&type=pd f (accessed 10 March 2015).

Michailova, S. and Husted, K. (2003), "Knowledge-Sharing Hostility in Russian Firms", California Management Review, Vol. 45 No. 3, pp. 59 -77.

Mikkonen, T., Vaden, T. and Vainio, N. (2007), "The Protestant Ethic Strikes Back: Open Source Developers and the Ethic of Capitalism", First Monday, available at http://www.firstmonday.org/ojs/index.php/fm/article/view/1623 (accessed 10 March 2015)

Nelson, R. R. and Winter, S. G. (1982), An Evolutionary Theory of Economic Change, Harvard University Press, Cambridge, M.A.

Nonaka, I. and Takeuchi, H. (1995), "The Knowledge Creating Company: How Japanese Companies Create the Dynamics of Innovation, Oxford University Press, New York.

Pallant, J. (2007), "SPSS Survival Manual, Open University Press, Maidenhead.

Podsakoff, P. M., Mackenzie, S. B., Lee, J. Y. and Podsakoff, N. P. (2003), "Common Method Biases in Behavioral Research: A Critical Review of the Literature and Recommended Remedies", Journal of Applied Psychology, Vol. 88, No. 5, pp. 879-903.

Polanyi, M. (1967), The Tacit Dimension, Routledge and Kegan Paul Imprint, London.

Prasarnphanich, P. and Wagner, C. (2011), "Explaining the Sustainability of Digital Ecosystems based on the Wiki Model Through Critical-Mass Theory", IEEE Transactions on Industrial Electronics, Vol. 58, pp. 2065-2072.

Raymond, E. (1999), The Cathedral and the Bazaar. Misusing on Linux and Open Source by an Accidental Revolutionary, O'Reilly, Sebastopol, CA.

Renzl, B. (2008), "Trust in Management and Knowledge Sharing: The Mediating Effects of Fear and Knowledge Documentation", Omega, Vol. 36, pp. 206-220.

Roberts, J. (2000), "From Know-How to Show-How? Questioning the Role of Information and Communication Technologies in Knowledge Transfer", Technology Analysis and Strategic Management, Vol. 12 No. 4, pp. 429 - 443.

Roberts, J. (2001), "The Drive to Codify: Implications for the Knowledge-Based Economy", Prometheus, Vol. 19 No. 2, pp. 99 - 116.

Roberts, J. (2014), "Community and the Dynamics of Spatially Distributed Knowledge Production: The case of Wikipedia", in Roel Rutten, Paul Benneworth, Dessy Irawati and Frans Boekema (eds), "The Social Dynamics of Innovation Networks: From Learning Region to Learning in Socio-Spatial Context, Routledge, New York and London, 179-200.

Rolandsson, B., Bergquist, M. and Ljungberg, J. (2011), "Open Source in the Firm: Opening up Professional Practices of Software Development”, Research Policy, Vol. 40, pp. 576-587.

Roscoe, J. T. (1975), Fundamental Research Statistics for the Behavioral Sciences, Holt, Rinehart, and Winston, Inc., New York.

Rullani, F. (2006), "Dragging Developers Towards the Core. How the Free / Libre / Open Source Software Community Enhances Developers' Contribution”, Free / Open Source Research Community, available at http://www.lem.sssup.it/WPLem/files/2006-22.pdf (accessed 12 March 2015).

Ruuska, I. and Vartiainen, M. (2005), "Characteristics of Knowledge Sharing Communities in Project Organizations", International Journal of Project Management, Vol. 23, pp. 374379.

Saviotti, P.P. (1998), "On the Dynamics of Appropriability of Tacit and Codified Knowledge", Research Policy, Vol. 26, pp. 843-856.

Scarbrough, H., Swan, J. and Preston, J. (1999), Knowledge Management: A Literature Review, Chartered Institute of Personnel and Development, London. 
Schmidt, D. C. and Porter, A. (2001), "Leveraging Open-Source Communities to Improve the Quality and Performance of Open-Source Software", available at http://citeseerx.ist.psu.edu/viewdoc/download?doi=10.1.1.20.9849\&rep=rep1\&type=pd f (accessed 12 March 2015).

Schroer, J. and Hertel, G. (2007), "Voluntary Engagement in an Open Web-Based Encyclopaedia: Wikipedians, and Why They Do It", Free / Open Source Research Community, available at http://ifipwg213.org/system/files/Schroer_Hertel_Wikipedia_Motivation.pdf (accessed 12 March 2015).

Sekaran, U. (2003), Research Methods for Business: A Skill Building Approach, John Wiley and Sons, Danvers, MA.

Shin, Y. (2004), "A Person-Environment Fit Model for Virtual Organizations”, Journal of Management, Vol. 30, pp. 725-743.

Sowe, S. K., Stamelos, I. and Angelis, L. (2008), "Understanding Knowledge Sharing Activities in Free/Open Source Software Projects: An Empirical Study", The Journal of Systems and Software, Vol. 81, pp.431-446.

Spender, J.-C. (1996), "Making Knowledge the Basis of a Dynamic Theory of the Firm", Strategic Management Journal, Winter 17, Winter Special Issue, 45 -62.

Staples, D. S. and Ratnasingham, P. (1998), “Trust: The Panacea of Virtual Management?" ICIS 1998 Proceedings, Paper 12, available at http://aisel.aisnet.org/icis1998/12 (accessed 12 March 2015).

Szulanski, G. (1996), "Exploring Internal Stickiness: Impediments to the Transfer of Best Practice within the Firm", Strategic Management Journal, Vol. 17, pp. 27-43.

Tabachnick, B.G. and Fidell, L.S. (2007), Using Multivariate Statistics, Pearson Education, Boston, MA.

Ulhoi, J. P. (2004), “Open Source Development: A Hybrid in Innovation and Management Theory", Management Decision, Vol. 42, pp. 1095 - 1114.

Van Den Hooff, B. and Huysman, M. (2009), "Managing Knowledge Sharing: Emergent and Engineering Approaches", Information and Management, Vol. 46, pp. 1-8.

Von Hippel, E. (1994), “"Sticky Information” and the Locus of Problem Solving: Implications for Innovation", Management Science, Vol. 40 No. 4, pp. 429-439.

Von Krogh, G. and Von Hippel, E. L. (2003), "Special Issue on Open Source Software Development", Research Policy, Vol. 32, pp. 1149-1157.

Wasko, M. and Faraj, S. (2000), “It Is What One Does': Why People Participate and Help Others in Electronic Communities of Practice", Journal of Strategic Information Systems, Vol. 9, pp. 155-173.

Wenger, E., McDermott, R., and Snyder, W. M. (2002), Cultivating Communities of Practice: A Guide to Managing Knowledge, Harvard Business School Press, Boston, MA.

Witherspoon, C.L., Bergner, J., Cockrell, C. and Stone, D.N. (2013), "Antecedents of Organizational Knowledge Sharing: A Meta-Analysis and Critique", Journal of Knowledge Management, Vol. 17 No. 2, pp. 250-277.

Young, M.L. (2014), "The Formation of Concern for Face and its Impact on Knowledge Sharing Intention in Knowledge Management Systems", Knowledge Management Research and Practice, Vol. 12 No. 1, pp. 36-47. 
Table 1 Motivations to share knowledge in OSS Communities

\begin{tabular}{|c|c|c|}
\hline Category & Motivation & Literature \\
\hline Hobbies & $\begin{array}{l}\text { Intrinsic motivations, } \\
\text { enjoyment of the work itself }\end{array}$ & $\begin{array}{l}\text { Prasarnphanich \& Wagner, 2011; Mikkonen, Vaden \& } \\
\text { Vainio, 2007; Hertel, Niedner \& Herrmann, 2003; } \\
\text { Lakhani \& von Hippel, } 2002\end{array}$ \\
\hline $\begin{array}{l}\text { Philosophical } \\
\text { Factors }\end{array}$ & $\begin{array}{l}\text { "Fight" against proprietary } \\
\text { software }\end{array}$ & $\begin{array}{l}\text { Prasarnphanich \& Wagner, 2011; Chang \& Chuang, 2011; } \\
\text { Baytiyeh \& Pfaffman, 2010; Rullani, 2006; Ulhoi, 2004; } \\
\text { Bonaccorsi \& Rossi, 2003 }\end{array}$ \\
\hline Accomplishment & $\begin{array}{l}\text { Feeling of solidarity, feeling of } \\
\text { efficiency, reputation }\end{array}$ & $\begin{array}{l}\text { Baytiyeh \& Pfaffman, 2010; Mikkonen, Vaden \& Vainio, } \\
\text { 2007; Schroer \& Hertel, 2007; Rullani, 2006; Ulhoi, 2004; } \\
\text { Bonaccorsi \& Rossi, 2003 }\end{array}$ \\
\hline Altruism & Self-determination, Altruism & $\begin{array}{l}\text { Prasarnphanich \& Wagner, 2011; Chang \& Chuang, 2011; } \\
\text { Baytiyeh \& Pfaffman, 2010; Sowe, Stamelos and Angelis, } \\
\text { 2008; Rullani, 2006; Ulhoi, 2004; Hertel, Niedner \& } \\
\text { Herrmann, 2003; Bonaccorsi \& Rossi, 2003; Hars \& Ou, } \\
\text { 2002; Lakhani \& von Hippel, } 2002\end{array}$ \\
\hline $\begin{array}{l}\text { Network } \\
\text { Opportunities }\end{array}$ & $\begin{array}{l}\text { Learning, Social interaction / } \\
\text { prestige, Reciprocation, Peer's } \\
\text { respect and recognition, } \\
\text { Community identification }\end{array}$ & $\begin{array}{l}\text { Sowe, Stamelos and Angelis, 2008; Schroer \& Hertel, } \\
\text { 2007; Rullani, 2006; Ulhoi, 2004; Hertel, Niedner \& } \\
\text { Herrmann, 2003; Bonaccorsi \& Rossi, 2003; Hars \& Ou, } \\
\text { 2002; Lakhani \& von Hippel, 2002; Faraj \& Wasko, } 2001\end{array}$ \\
\hline Personal Needs & $\begin{array}{l}\text { Community identification, } \\
\text { Personal challenges to improve } \\
\text { existing software for own needs }\end{array}$ & $\begin{array}{l}\text { Prasarnphanich \& Wagner, 2011; Chang \& Chuang, 2011; } \\
\text { Sowe, Stamelos and Angelis, 2008; Rullani, 2006; Ulhoi, } \\
\text { 2004; Hertel, Niedner \& Herrmann, 2003; Bonaccorsi \& } \\
\text { Rossi, 2003; Hars \& Ou, 2002; Lakhani \& von Hippel, } \\
2002\end{array}$ \\
\hline $\begin{array}{l}\text { Main Work } \\
\text { Needs }\end{array}$ & $\begin{array}{l}\text { Needs in the main work, Part of } \\
\text { the main work, The software is } \\
\text { critical for the main work, } \\
\text { Information gathering, } \\
\text { Developing knowledge for the } \\
\text { main work }\end{array}$ & $\begin{array}{l}\text { Mikkonen, Vaden \& Vainio, 2007; Rullani, 2006; Ulhoi, } \\
\text { 2004; Bonaccorsi \& Rossi, 2003; Lakhani \& von Hippel, } \\
2002\end{array}$ \\
\hline
\end{tabular}


Table 2: Measurements of the variables / factor analysis

\begin{tabular}{|c|c|c|c|}
\hline Variables & $\begin{array}{l}\text { Measurements } \\
\text { (Derived from the questionnaire see Appendix 1) }\end{array}$ & $\begin{array}{l}\text { Cronbach's } \\
\text { Alpha } \\
\text { Reliability } \\
\text { Statistics }\end{array}$ & $\begin{array}{l}\text { Rotated } \\
\text { Component } \\
\text { Matrix }\end{array}$ \\
\hline $\begin{array}{l}\text { Dependent } \\
\text { Variable - } \\
\text { Motivations }\end{array}$ & $\begin{array}{ll}\text { 1. } & \text { Hobbies } \\
\text { 2. } & \text { Philosophical factors } \\
\text { 3. } & \text { Accomplishment } \\
\text { 4. } & \text { Altruism } \\
\text { 5. } & \text { Network opportunities } \\
\text { 6. } & \text { Personal needs } \\
\text { 7. } & \text { Main work needs }\end{array}$ & $\begin{array}{ll}1 . & .865 \\
2 . & .721 \\
\text { 3. } & .878 \\
\text { 4. } & .782 \\
\text { 5. } & .823 \\
\text { 6. } & .735 \\
\text { 7. } & .781\end{array}$ & $>0.5$ \\
\hline $\begin{array}{l}\text { Moderating } \\
\text { Variable - } \\
\text { Management }\end{array}$ & $\begin{array}{l}\text { 1. Satisfaction with the management of an OSS } \\
\text { Community } \\
\text { 2. Receiving the needed information on time } \\
\text { 3. Guidance from the project administrator } \\
\text { 4. Satisfaction with supervision } \\
\text { 5. Satisfaction with organisational commitment } \\
\text { 6. Satisfaction with co-workers }\end{array}$ & .862 & $>0.5$ \\
\hline $\begin{array}{l}\text { Independent } \\
\text { Variable - } \\
\text { Knowledge } \\
\text { Sharing }\end{array}$ & $\begin{array}{l}\text { 1. Individuals' frequency of communication with } \\
\text { members of the community (FREQ COM) } \\
\text { 2. Hours per week knowledge shared in the OSS } \\
\text { project (HOURS PER WK) } \\
\text { 3. A percentage of the participation related to project } \\
\text { development in the OSS community (\% PART } \\
\text { PROJ DEV) }\end{array}$ & .818 & $>0.5$ \\
\hline
\end{tabular}


Table 3 Correlations analysis

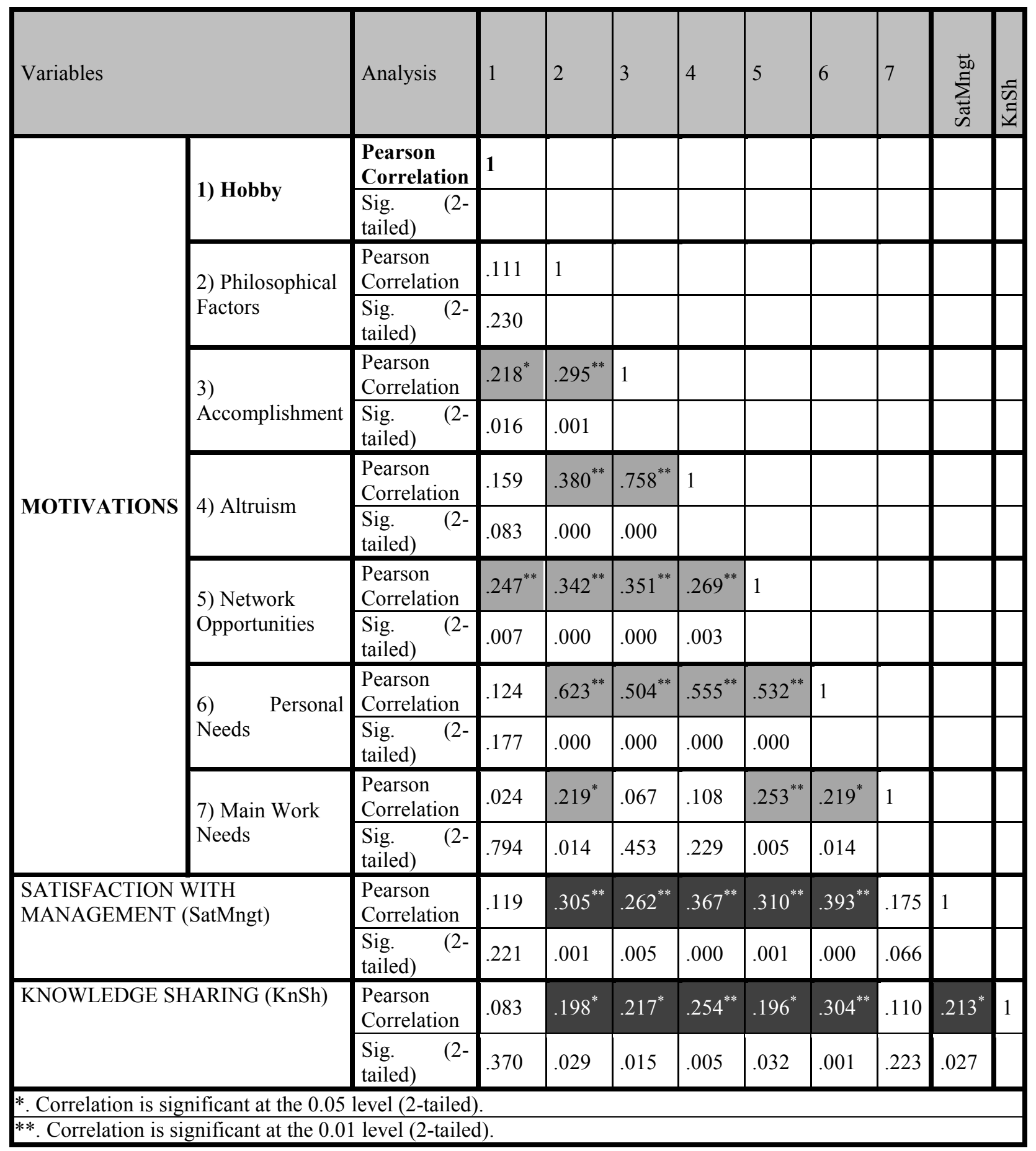




\section{Table 4 Multiple regression analysis}

a) Summary

\begin{tabular}{|c|c|c|c|c|c|c|}
\hline \multicolumn{2}{|c|}{$\begin{array}{l}\text { Dependent } \\
\text { variable }\end{array}$} & Model & $\mathrm{R}$ & R Square & $\begin{array}{l}\text { Adjusted } \\
\text { R Square }\end{array}$ & $\begin{array}{l}\text { Std. Error of } \\
\text { the Estimate }\end{array}$ \\
\hline \multirow{14}{*}{ MOTIVATIONS } & \multirow{2}{*}{ Hobby } & 1 & $.185^{\mathrm{a}}$ & .034 & -.005 & .97195 \\
\hline & & 2 & $.200^{\mathrm{b}}$ & .040 & -.009 & .97391 \\
\hline & \multirow{2}{*}{$\begin{array}{l}\text { Philosophical } \\
\text { Factors }\end{array}$} & 1 & $.278^{\mathrm{a}}$ & .077 & .040 & .79469 \\
\hline & & 2 & $.399^{b}$ & .159 & .117 & .76229 \\
\hline & \multirow{2}{*}{ Accomplishment } & 1 & $.259^{\mathrm{a}}$ & .067 & .030 & .88523 \\
\hline & & 2 & $.353^{b}$ & .124 & .080 & .86204 \\
\hline & \multirow{2}{*}{ Altruism } & 1 & $.311^{\mathrm{a}}$ & .097 & .060 & .78328 \\
\hline & & 2 & $.448^{b}$ & .201 & .160 & .74067 \\
\hline & \multirow{2}{*}{$\begin{array}{l}\text { Network } \\
\text { Opportunities }\end{array}$} & 1 & $.237^{\mathrm{a}}$ & .056 & .018 & .71908 \\
\hline & & 2 & $.378^{\mathrm{b}}$ & .143 & .099 & .68863 \\
\hline & \multirow{2}{*}{$\begin{array}{l}\text { Personal } \\
\text { Needs }\end{array}$} & 1 & $.418^{\mathrm{a}}$ & .175 & .141 & .64707 \\
\hline & & 2 & $.553^{\mathrm{b}}$ & .306 & .270 & .59655 \\
\hline & \multirow{2}{*}{$\begin{array}{l}\text { Main Work } \\
\text { Needs }\end{array}$} & 1 & $.143^{\mathrm{a}}$ & .020 & -.019 & 1.32547 \\
\hline & & 2 & $.212^{b}$ & .045 & -.004 & 1.31552 \\
\hline
\end{tabular}

a. Predictors: (Constant), KNOWLEDGE SHARING

b. Predictors: (Constant), KNOWLEDGE SHARING, SATISFACTION WITH

MANAGEMENT 
b) Anova

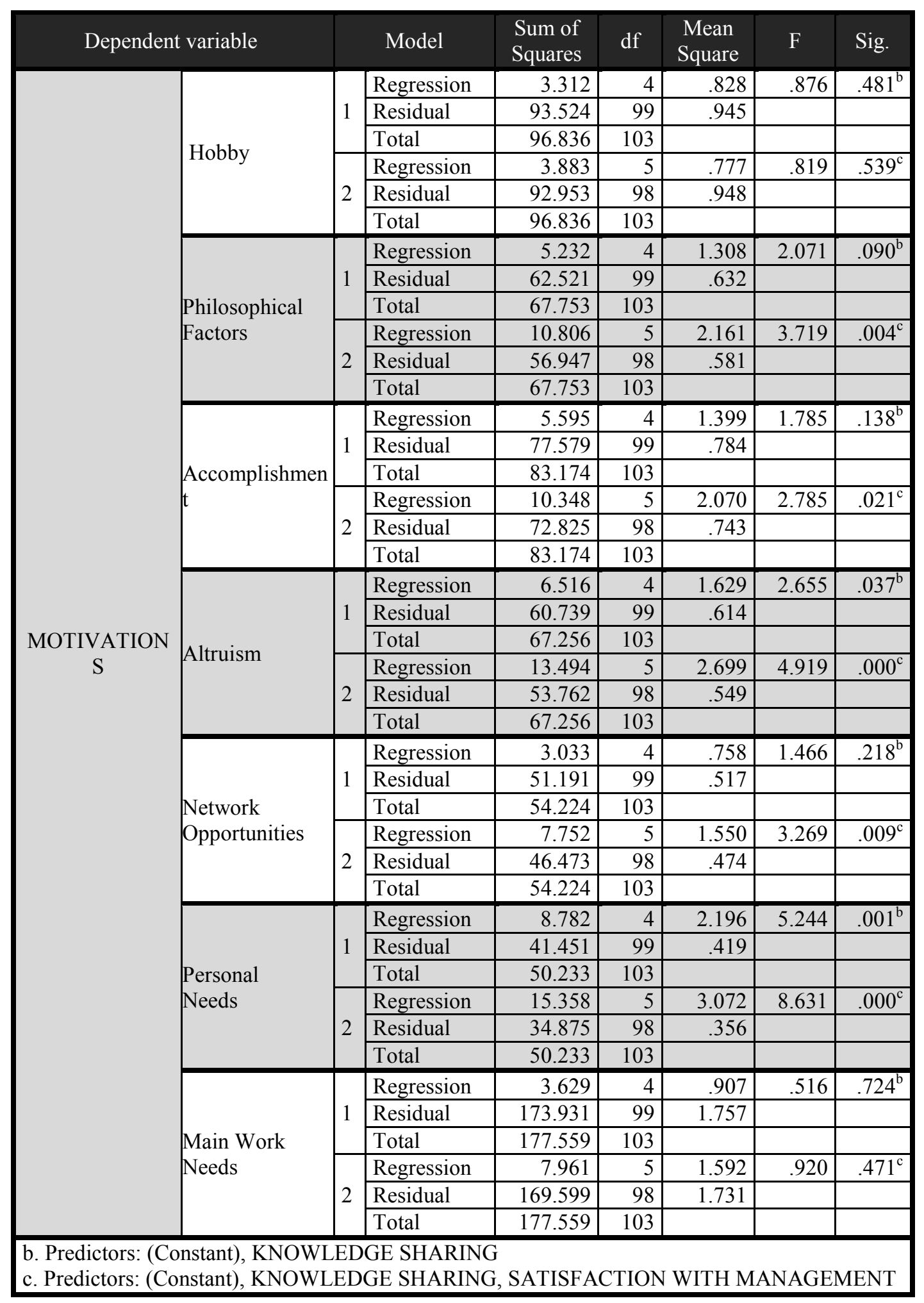


c) Coefficients

\begin{tabular}{|c|c|c|c|c|c|c|c|c|c|c|c|c|c|c|c|c|c|c|c|c|c|c|}
\hline \multirow{2}{*}{\multicolumn{2}{|c|}{ Coefficients }} & \multicolumn{21}{|c|}{ MOTIVATIONS } \\
\hline & & \multicolumn{3}{|c|}{ Hobby } & \multicolumn{3}{|c|}{$\begin{array}{l}\text { Philosophical } \\
\text { Factors }\end{array}$} & \multicolumn{3}{|c|}{ Accomplishment } & \multicolumn{3}{|c|}{ Altruism } & \multicolumn{3}{|c|}{$\begin{array}{c}\text { Network } \\
\text { Opportunities }\end{array}$} & \multicolumn{3}{|c|}{ Personal Needs } & \multicolumn{3}{|c|}{$\begin{array}{l}\text { Main Work } \\
\text { Needs }\end{array}$} \\
\hline & Model &  & $\mathrm{t}$ & Sig. & 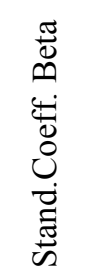 & $\mathrm{t}$ & Sig. & 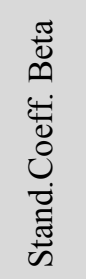 & $\mathrm{t}$ & Sig. & 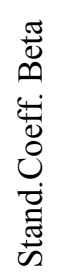 & $\mathrm{t}$ & Sig. & 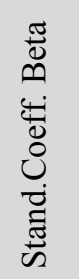 & $\mathrm{t}$ & Sig. & 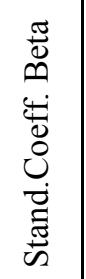 & $\mathrm{t}$ & Sig. &  & $\mathrm{t}$ & Sig. \\
\hline \multirow[b]{2}{*}{1} & (Constant) & & 6.126 & .000 & & 6.329 & .000 & & 5.501 & .000 & & 6.039 & .000 & & 7.492 & .000 & & 8.428 & .000 & & 3.447 & .001 \\
\hline & $\begin{array}{l}\text { KNOWLEDGE } \\
\text { SHARING } \\
\end{array}$ & .041 & .372 & .711 & .280 & 2.631 & .010 & .255 & 2.379 & .019 & .316 & 2.993 & .003 & .208 & 1.927 & .057 & .412 & 4.084 & .000 & .110 & 1.002 & .319 \\
\hline \multirow[b]{3}{*}{2} & \begin{tabular}{|l|} 
(Constant) \\
\end{tabular} & & 4.336 & .000 & & 3.286 & .001 & & 2.889 & .005 & & 2.830 & .006 & & 4.216 & .000 & & 4.549 & .000 & & 1.759 & .082 \\
\hline & $\begin{array}{l}\text { KNOWLEDGE } \\
\text { SHARING }\end{array}$ & .028 & .252 & .801 & .233 & 2.255 & .026 & .215 & 2.042 & .044 & .262 & 2.603 & .011 & .159 & 1.524 & .131 & .352 & 3.746 & .000 & .084 & .764 & .447 \\
\hline & $\begin{array}{l}\text { SATISFACTION } \\
\text { WITH } \\
\text { MANAGEMENT }\end{array}$ & .081 & .776 & .440 & .301 & 3.097 & .003 & .251 & 2.529 & .013 & .339 & 3.566 & .001 & .310 & 3.154 & .002 & .380 & 4.298 & .000 & .164 & 1.582 & .117 \\
\hline
\end{tabular}

Significance level: $\mathrm{p}<.05^{*} ; \mathrm{p}<.01^{* *} ; \mathrm{p}<.001^{* * *}$ 


\section{Appendix: Extract from the online questionnaire}

(Due to space restrictions this table includes only questions that were used to test the hypothesis. The full questionnaire is available on request from the corresponding author.)

\section{A) Personal details}

1. Your gender is: $\mathbf{C}_{\mathrm{M}} \mathbf{C}{ }_{\mathrm{F}} \boldsymbol{C}$ Prefer not to say

2. Your age is:

3. You are from:

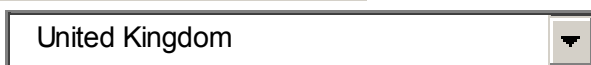

4. Your highest education attainment is:

$\mathbf{C}{ }_{\mathrm{PhD}} \mathbf{C}$ Master level (MSc, MA, MBA) $\mathbf{C}$ Undergraduate level $\boldsymbol{C}$ High school graduation

C Other, please specify

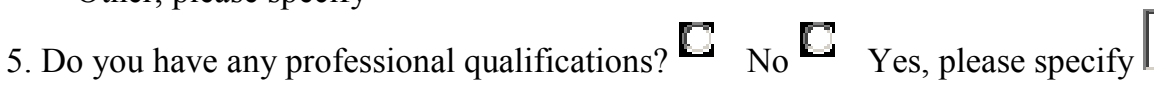

6. Your primary occupation is: (please indicate all that apply)
Г IT Employee $\square$
IT, Self-Employed $Г$
In employment other than IT
Below university or undergraduate level student $\square$ Postgraduate student ${ }^{\square} \operatorname{PhD}$ student ${ }^{\square}$ Retired/Not working $\square$ Other, please specify

7. Which languages do you use frequently? (please indicate all that apply)

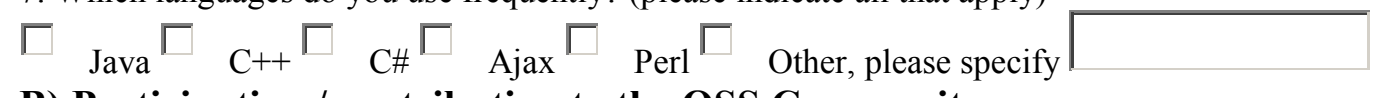

\section{B) Participation / contribution to the OSS Community}

1. How often do you communicate with other members in the OSS Community?

$\mathbf{C}$ Every day $\mathbf{C}$ Nearly every day $\mathbf{C}$ Once/twice in a week $\mathbf{C}$ Once/twice in a month $\mathbf{C}$ Other, please specify

2. On average how many hours per week do you contribute to the OSS Community?

3. What percentage of your participation is related with project development in the OSS Community? $\overline{\%}$

\section{C) Motivations \& benefits of contributing to the OSS Community}

Rating as appropriate from 5 - "strongly agree" to 1 - "strongly disagree".

1. What are your personal motivations to contribute to the OSS Community?

Hobby

a) I enjoy writing programs. $\boldsymbol{C}_{5} \boldsymbol{C}_{4} \boldsymbol{C}_{3} \boldsymbol{C}_{2} \boldsymbol{C}_{1}$

b) Programming gives me a chance to do what I can do the best. $\mathbf{C}_{5} \mathbf{C}_{4} \mathbf{C}_{3} \mathbf{C}_{2} \mathbf{C}_{1}$

c) I spend my free time with programming. $\boldsymbol{C}_{5} \boldsymbol{C}_{4} \boldsymbol{C}_{3} \boldsymbol{\square}_{2} \boldsymbol{\square}_{1}$

d) Programming is my favourite activity. $\mathbf{C}_{5} \mathbf{C}_{4} \mathbf{C}_{3} \mathbf{C}_{2} \mathbf{C}{ }_{1}$

e) I cannot imagine my life without programming. $\mathbf{C}_{5} \mathbf{C}_{4} \mathbf{C}_{3} \mathbf{C}_{2} \mathbf{C}_{1}$

Psychological factors

f) I enjoy helping other people. $\mathbf{C}_{5} \mathbf{C}_{4} \mathbf{C}_{3} \mathbf{C}_{2} \mathbf{C}_{1}$

g) I have altruistic approach in communication with other people. $\mathbf{C}_{5} \mathbf{C}_{4} \mathbf{C}_{3} \mathbf{C}_{2} \mathbf{C}{ }_{1}$

h) It gives me the feeling of success. $\boldsymbol{C}_{5} \mathbf{C}_{4} \mathbf{C}_{3} \mathbf{C}_{2} \boldsymbol{C}_{1}$ 


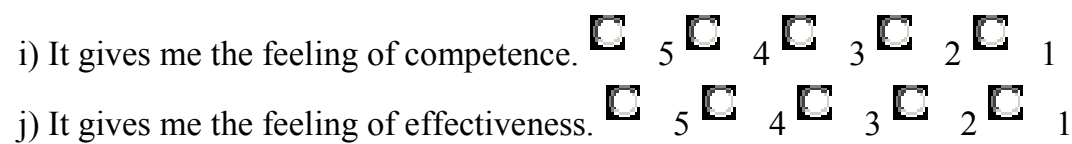

Philosophical factors

k) I believe software should be free. $\boldsymbol{C}_{5} \mathbf{C}_{4} \mathbf{C}_{3} \mathbf{C}_{2} \mathbf{C}_{1}$

1) OSS is more secure than commercialised software. $\mathbf{C}_{5} \mathbf{C}_{4} \mathbf{C}{ }_{3} \mathbf{C}_{2} \mathbf{C}{ }_{1}$

m) OSS is more updated than commercialised software. ${ }^{{ }_{5}} \mathbf{C}_{4} \mathbf{C}_{3} \mathbf{C}_{2} \mathbf{C}_{1}$

n) I contribute to the OSS Community because of reciprocal approach. $\boldsymbol{C}_{5} \mathbf{C}_{4} \boldsymbol{C}_{3} \boldsymbol{C}_{2} \mathbf{C}_{1}$

o) I want to be one who creates free software available for using by everybody. ${ }{ }_{5} C_{4} C_{3} C_{2}$

C 1

2. What are your professional motivations to contribute to the OSS Community?

Main work needs

a) The software itself is my main job. $\mathbf{C}_{5} \mathbf{C}_{4} \mathbf{C}_{3} \mathbf{C}_{2} \mathbf{C}{ }_{1}$

b) The software is critical for my main job. $\boldsymbol{C}_{5} \mathbf{C}_{4} \boldsymbol{C}_{3} \boldsymbol{C}_{2} \boldsymbol{C}_{1}$

c) I prefer individualistic approach in my work. $\mathbf{C}_{5} \mathbf{C}_{4} \mathbf{C}_{3} \mathbf{C}_{2} \mathbf{C}_{1}$

d) Increases my social prestige (social competence and skills). $\mathbf{C}_{5} \mathbf{C}{ }_{4} \mathbf{C}_{3} \mathbf{C}_{2} \mathbf{C}{ }_{1}$

Personal needs

e) I use OSS myself (excluding programming or testing activities). $\mathbf{C}_{5} \mathbf{C}{ }_{4} \mathbf{C}{ }_{3} \mathbf{C}_{2} \mathbf{C}{ }_{1}$

f) The software provides functionality that matches my unique and specific needs.

\section{$\mathbb{C}_{5} \mathbf{C}_{4} \mathbf{C}_{3} \mathbf{C}_{2} \mathbf{C}_{1}$}

g) Improves the level of my programming skills. $\mathbf{C}_{5} \mathbf{C}_{4} \mathbf{C}_{3} \mathbf{C}_{2} \mathbf{C}_{1}$

h) Gives me extra opportunities for learning. $\boldsymbol{C}_{5} \mathbf{C}_{4} \boldsymbol{C}_{3} \boldsymbol{C}_{2} \boldsymbol{C}_{1}$

i) I like sharing my knowledge and skills. $\mathbb{C}_{5} \mathbf{C}_{4} \mathbf{C}_{3} \mathbf{C}_{2} \mathbf{C}_{1}$

Network opportunities

j) To exchange advice and solutions with knowledgeable people. $\mathbf{C}_{5} \mathbf{C}_{4} \mathbf{C}_{3} \mathbf{C}_{2} \mathbf{C}{ }_{1}$

k) To keep abreast of new ideas and innovations. $\mathbf{C}_{5} \mathbf{C}_{4} \mathbf{C}_{3} \mathbf{C}_{2} \mathbf{C}{ }_{1}$

1) To be one of the team who produce the innovative software. ${ }^{\mathbf{C}}{ }_{5} \mathbf{C}_{4} \boldsymbol{C}_{3} \mathbf{C}_{2} \mathbf{C}_{1}$

m) To be meet new and different people. ${ }^{-} \boldsymbol{C}_{4} \boldsymbol{C}_{3} \boldsymbol{C}_{2} \mathbf{C}{ }_{1}$

3. What are the long-term benefits of contributing to the OSS Community for you?

a) After participating the OSS Community, I can improve career progression prospects.

$\mathbf{C}_{5} \mathbf{C}_{4} \mathbf{C}_{3} \mathbf{C}_{2} \mathbf{C}_{1}$

b) After participating the OSS Community, I can increase my income in my main work place.

$\mathbf{C}_{5} \mathbf{C}_{4} \mathbf{C}_{3} \mathbf{C}_{2} \mathbf{C}_{1}$

c) After participating the OSS Community, I can increase my income from additional activities by using OSS.

$\mathbf{C}_{5} \mathbf{C}_{4} \mathbf{C}_{3} \mathbf{C}_{2} \mathbf{C}_{1}$ 
d) I will establish my own business by selling consulting, training, implementation or customisation services related to the project. $\boldsymbol{C}_{5} \boldsymbol{C}_{4} \boldsymbol{C}_{3} \boldsymbol{C}_{2} \boldsymbol{C}_{1}$

\section{D) Management in the OSS Community}

1. When you add new code, who accepts it?

$\square$ Peer review $\square$ Project Administrator $\square$ Other, please specify

2. Is there a clearly identifiable person who coordinates your OSS Community?

$\mathbb{C}_{\text {No }} \mathrm{C}_{\text {Yes, please specify }} \mathrm{C}_{\mathrm{N} / \mathrm{A}}$

3. With whom from the following hierarchical staff have you had contacts in your OSS project/s? (please indicate all that apply)

$\square$ Forum/Project moderators $\square$ Your peers
$\square$ Other, please specify

4. Are you satisfied with the management of your OSS Community?

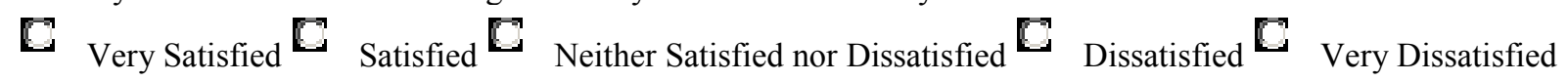
Questions 5-9 - Rating as appropriate from 5 - "strongly agree" to 1 - "strongly disagree".

5. I receive on time the information needed to do my job in the OSS Community.

$\boldsymbol{D}_{5} \boldsymbol{C}_{4} \boldsymbol{C}_{3} \boldsymbol{D}_{2} \boldsymbol{D}_{1}$

6. The Project Administrator offers guidance for solving job-related problems.

$\mathbb{C}_{5} \boldsymbol{C}_{4} \boldsymbol{C}_{3} \boldsymbol{C}_{2} \boldsymbol{C}_{1}$

7. I am satisfied with the supervision in the Oss Community. ${ }_{5}{ }_{5}{ }_{4}{ }_{3}{ }_{2}{ }_{2}{ }_{1}$

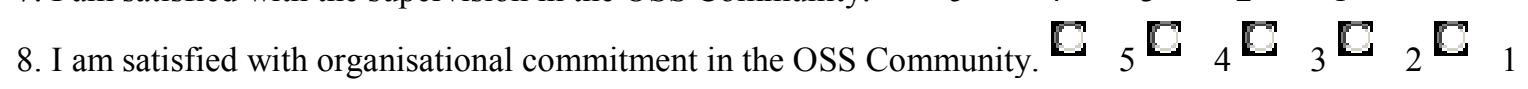



10. Do you gain any monetary rewards for your contribution to the OSS Community? ${ }^{\mathbf{C}}$ Yes No

11. Who appointed you to your position in the OSS Community?

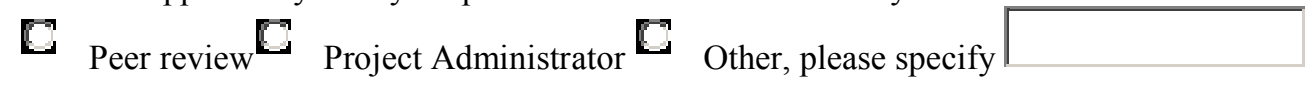

12. Are you a formal employee or a volunteer contributor in the OSS Community?

$\boldsymbol{C}$ A formal employee $\mathbb{D}$ A volunteer $\mathbb{D}$ Other, please specify 